\title{
Protransforming Growth Factor Alpha
}

National Cancer Institute

\section{Source}

National Cancer Institute. Protransforming Growth Factor Alpha. NCI Thesaurus. Code C118440.

Protransforming growth factor alpha (160 aa, 17 kDa) is encoded by the human TGFA gene. This protein plays a role in cell proliferation. 